\title{
Undetectable IgE responses after respiratory syncytial virus infection
}

\author{
G L Toms, R Quinn, J W Robinson
}

\begin{abstract}
Sequential nasopharyngeal secretions were collected from 81 infants from one day to three months after admission to hospital with respiratory syncytial virus (RSV) infection. Samples from 21 infants were assayed for anti-RSV IgE in an antigen capture ELISA assay. No IgE antibodies were detected although an assay of Ig $A$ antibodies carried out in parallel by a similar technique detected IgA antibodies in the secretions of all patients tested. Neither prior absorption of IgA or IgG, concentration of the secretions by freeze drying, nor enzyme amplification of the assay revealed any virus specific IgE. Using an antibody capture ELISA with a sensitivity of $0.85 \mathrm{IU} / \mathrm{ml}$, IgE could be detected in sequential secretions of only one of the $81 \mathrm{RSV}$ infected infants studied. Further testing of the secretions from 12 of these patients and those of a further 15 using an enzyme amplified assay with a sensitivity of $0.1 \mathrm{IU} / \mathrm{ml}$ revealed no further positives.

Low concentrations of IgE were found in the sera of the majority of infants with RSV infection but they did not differ from those of virus negative children of a similar age collected between RSV epidemics. No rise in mean serum IgE concentrations between acute and convalescent samples was observed. No virus specific IgE was detected in the sera of any infant using the enzyme amplified antigen capture ELISA. (Arch Dis Child 1996; 74: 126-130)
\end{abstract}

Keywords: IgE, respiratory syncytial virus infection.

The majority of infants experience a primary infection with respiratory syncytial virus (RSV) in their first year of life. One to two per cent of them are severely affected and admitted to hospital, most frequently suffering from bronchiolitis. ${ }^{1}$ Recovery, with virus clearance, is generally rapid but wheezing episodes may persist for several years. ${ }^{2}$ The pathogenesis of RSV bronchiolitis is poorly understood. Gardner et al, carried out histopathological investigations of a small number of babies who died with RSV infection, and observed that infants with bronchiolitis had less antigen in their lungs than those with pneumonia. ${ }^{3}$ They suggested that bronchiolitis may result from a type 1 allergic reaction, mediated by IgE antibody, rather than direct virus damage.

Contrary to this hypothesis atopy does not predispose to RSV bronchiolitis ${ }^{4}$ and IgE concentrations in the blood of infants with RSV bronchiolitis are not raised. ${ }^{5}$ However, Welliver et $a l^{6}$ demonstrated IgE antibodies bound to RSV infected cells in the nasal secretions of infected infants and later ${ }^{7}$ free virus specific IgE in the nasal secretions using an antigen capture enzyme linked immunosorbent assay (ELISA). Cell bound IgE peaked in the acute phase but free IgE antibodies rose progressively after infection and both correlated with bronchiolitis and wheezing but not with upper respiratory tract infection or pneumonia. These findings have not been confirmed in other laboratories. However, Bui et al, ${ }^{8}$ using an antigen capture radioimmunoassay, demonstrated anti-RSV IgE in the acute serum of infants with RSV infection, again correlating with wheezing and bronchiolitis. Collins et al also claim to have detected IgE antibodies in nasal secretions but could find no correlation with disease type. ${ }^{9}$

In view of the central importance of these observations to our understanding of the pathogenesis of bronchiolitis we have set out to quantitate anti-RSV IgE antibodies in blood and nasal secretions of infected infants, initially using an antigen capture system similar to that used in earlier studies. Our failure to detect specific antiviral IgE in serum or nasal secretions using this assay led us to investigate the levels of total IgE in these samples using an enzyme amplified antibody capture assay of subnanogram sensitivity.

\section{Patients and methods}

NASOPHARYNGEAL SECRETIONS

Nasopharyngeal secretions were collected sequentially from 81 infants between 1 and 6 months of age admitted to hospital with laboratory diagnosed RSV infection. Samples were taken the day after diagnosis, at weekly intervals to three weeks and, thereafter, at monthly intervals to three months. Forty five infants were followed up successfully to two months but only 12 to three months. Secretions were transported on ice to the laboratory, diluted in $3 \mathrm{ml}$ of viral transport medium (HEPES buffered Parker's 199 medium containing $1 \% \mathrm{w} / \mathrm{v}$ bovine serum albumin). Secretions were also collected from a further $15 \mathrm{RSV}$ infected infants of similar age, the day after diagnosis in 12 and/or six weeks later in seven, and diluted in $2 \mathrm{ml}$ of Dulbecco's phosphate buffered saline (PBS, solution A). All secretions after dilution were frozen at $-70^{\circ} \mathrm{C}$ and thawed for assay. This study was approved by the Gateshead ethical committee.
Newcastle upon Tyne NE2 $4 \mathrm{HH}$

Accepted 20 September 1995 
SERA

Sera from 71 infants under 1 year of age with a clinical diagnosis of bronchiolitis, 62 of which were associated with RSV infection diagnosed by immunofluorescence staining, and from 11 uninfected control children of less than 1 year collected in between RSV epidemics, were provided by Professor $\mathbf{H}$ Simpson (Department of Child Health, University of Leicester). Convalescent serum samples, collected six weeks after infection, were available for 22 infants.

\section{ABSORPTION OF IgA AND IgE}

Secretions were diluted $1 / 2$ in rabbit antihuman colostrum IgA (alpha chains) and secretory component (Dakopatts) or rabbit antihuman IgG (gamma chains) (Dakopatts) both diluted $1 / 10$ in PBS containing $0.05 \%$ Tween $20,10 \%$ heat inactivated fetal calf serum, and $10 \%$ uninfected HeLa cell antigen (see below). After incubation for one hour at $37^{\circ} \mathrm{C}$ and overnight at $4^{\circ} \mathrm{C}$ immune complexes were pelleted at $10000 \mathrm{~g}$ for 10 minutes in a microfuge. The supernatant was titrated for IgE antibodies.

\section{VIRAL ANTIGENS}

Cell culture supernatants, from $\mathrm{HeLa}$ cells infected with the A2 strain of RSV, were precipitated with polyethylene glycol and purified by the method of Ueba ${ }^{10}$ on discontinuous followed by continuous sucrose gradients. Affinity purified $\mathrm{F}$ protein from RSV strain A2 was purified as described previously. ${ }^{11}$

\section{ANTIGEN CAPTURE RSV SPECIFIC ANTIBODY} ASSAY

Dynatech 129B micro-ELISA plates were coated overnight at $4^{\circ} \mathrm{C}$ with $50 \mu \mathrm{l} /$ well containing $4 \mu \mathrm{g} / \mathrm{ml}$ sucrose gradient purified RSV, $20 \mu \mathrm{g} / \mathrm{ml}$ (unless stated otherwise) of affinity purified $F$ protein, or uninfected HeLa cell culture ELISA antigen prepared as described by Nandapalan et al ${ }^{12}$ in carbonate buffer pH 9.6. The plates were kept moist at all times. After three washes in PBS containing 0.05\% Tween 20 , twofold dilutions of sample were prepared in the plate in $50 \mu \mathrm{l}$ volumes of wash buffer containing $10 \%$ heat inactivated fetal calf serum and $10 \%$ uninfected HeLa cell antigen. A human milk sample containing a known titre of anti-RSV IgA was titrated in each plate. After 90 minutes at $37^{\circ} \mathrm{C}$ the sample was washed off as above and bound immunoglobulin detected with either antihuman IgA (alpha chains) (Dakopatts) diluted 1/750 in wash buffer plus $10 \%$ heat inactivated fetal calf serum or $1 / 100$ peroxidase conjugated goat antihuman IgE (epsilon chain, ICN) in the same diluent. After 90 minutes at $37^{\circ} \mathrm{C}$ the conjugate was washed off as above and bound peroxidase was quantitated by incubation with $75 \mu \mathrm{l} /$ well of $0.4 \mathrm{mg} / \mathrm{ml}$ orthophenylene diamine (Sigma) in $0.025 \mathrm{M}$ citrate phosphate buffer $(\mathrm{pH} 5)$ containing hydrogen peroxide. After the addition of $50 \mu \mathrm{l} 3 \mathrm{M}$ sulphuric acid to each well optical densities were measured at $492 \mathrm{~nm}$ in a Multiscan spectrophotometer (Flow Laboratories).

\section{IgE ANTIBODY CAPTURE ELISA}

Wells of microtitre plates (Immunoplate 1, Gibco-Nunc) were coated overnight at $4^{\circ} \mathrm{C}$ with sheep antihuman IgE (Seward Laboratories at $1 / 500$ or Cappel Laboratories at $1 / 1000$ ) in carbonate buffer $\mathrm{pH} 9 \cdot 6$. After three washes in $0.5 \mathrm{M}$ sodium chloride, $0.5 \%$ Tween 20, a fourfold dilution series of each test sample was prepared in $50 \mu \mathrm{l}$ volumes of $0.5 \mathrm{M}$ sodium chloride, $1 \%$ Tween 20 in the plate. The plates were incubated at $37^{\circ} \mathrm{C}$ for 90 minutes, washed as above, and the captured IgE detected by incubation for 60 minutes at $37^{\circ} \mathrm{C}$ with $50 \mu \mathrm{l}$ of $1 / 400$ peroxidase conjugated rabbit antihuman IgE (Dakopatts) diluted in $0.5 \mathrm{M}$ sodium chloride, $1 \%$ Tween $20,1 \%$ normal lamb serum. Bound enzyme was quantitated as described above. The assay was standardised against the second international standard for IgE (kindly supplied by Dr R Thorpe, National Institute for Biological Standards and Control, Potters Bar, Hertfordshire) and by repeated titration of six human sera of known IgE content. An optical density of 0.2 above serum negative controls was found equivalent to $0.85 \mathrm{IU} / \mathrm{ml}(2 \mathrm{ng} / \mathrm{ml})$ and this level was adopted for titre determination. A pool of sera from laboratory personnel, negative for IgE at $1 / 100$, and a single serum containing $680 \mathrm{IU} / \mathrm{ml}$ were adopted as standards and stored in aliquots at $-70^{\circ} \mathrm{C}$. A fresh aliquot of each was titrated on every test plate.

ENHANCED DETECTION OF IgE BINDING

Enhanced detection of IgE binding was achieved by substituting an alkaline phosphatase conjugated monoclonal anti-IgE Fab' fragment (Novo-Nordisk) for the peroxidase conjugated anti-IgE in both the antigen capture anti-RSV assay and the IgE antibody capture assay. Quantitation of the conjugate bound was achieved with an Ampak III redox enzyme amplification kit (Novo-Nordisk) according to the manufacturer's instructions. In these assays optical densities greater than two standard deviations above the mean of the 'no serum' control wells tested in the same plate were taken as positive. Positive standard and negative pool (see above) gave IgE contents of $1021+/-192$ and $14 \cdot 2+/-2 \cdot 5 \mathrm{IU} / \mathrm{ml}$ when titrated repeatedly against an international research standard IgE capture assay. The sensitivity of the assay was $0 \cdot 1 \mathrm{IU} / \mathrm{ml}(240$ $\mathrm{pg} / \mathrm{ml}$ ).

\section{Results}

RSV SPECIFIC ANTIBODIES IN NASOPHARYNGEAL SECRETIONS

In a preliminary study 40 secretions collected over three months after infection from nine 


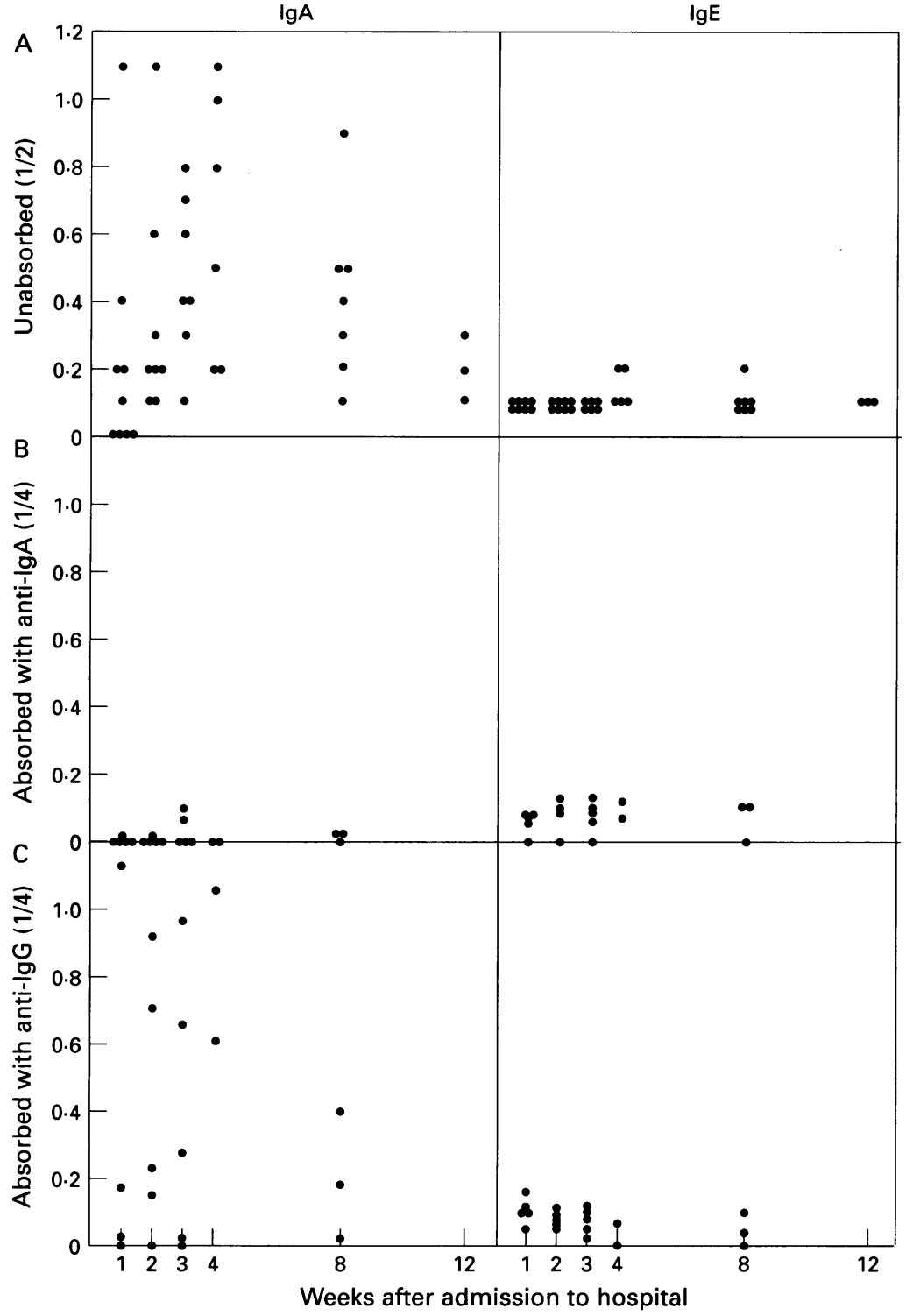

Figure 1 Detection of virus specific IgA and IgE antibodies in sequential nasopharyngeal secretions by antigen capture ELISA before and after absorption of IgA and IgG.

infants were titrated for IgA and IgE antibodies to sucrose gradient purified RSV (fig 1A). A single secretion kindly donated by $\mathrm{Dr} R$ Welliver and found in his laboratory to contain IgE to a titre of $1 / 16$ was tested at $1 / 4$.

All nine infants developed IgA antibodies detectable by this method. Parallel assays on the same specimens in which an anti-IgE peroxidase conjugate was substituted for anti-IgA peroxidase conjugate gave uniformly low binding never exceeding an optical density of $0 \cdot 2$. The secretion from Dr Welliver was also negative in this assay. In an antibody capture assay for $\operatorname{IgE}$ in serum this conjugate detected $\operatorname{IgE}$ at $3 \cdot 4 \mathrm{IU} / \mathrm{ml}$.

To preclude the possibility of IgA inhibition of IgE binding, IgA antibodies were absorbed from the secretions with sheep antihuman IgA before assay (Fig 1B). In 20 secretions from five patients all trace of specific IgA antibody was removed without any effect on binding in the IgE assay. The immunospecificity of absorption was tested by parallel treatment of the same sera with sheep antihuman IgG which had little or no effect on IgA antibody concentrations. This experiment was repeated with a further 20 secretions from 12 patients with similar results (not shown). Ten secretions from three patients were concentrated between threefold and fourfold by freeze drying and the experiment was repeated. Although IgA antibody titres increased with concentration, no effect on the levels of binding in the IgE assay was observed with or without IgA depletion.

Secretions taken from six RSV infected infants between 28 and 59 days after admission were tested at $1 / 2$ on plates coated with 20 $\mu \mathrm{g} / \mathrm{ml}$ of affinity purified respiratory syncytial A2 strain fusion protein. Three of these and a further six secretions were tested on plates coated with $600 \mu \mathrm{g} / \mathrm{ml}$ of the same antigen. Antifusion protein IgA was demonstrated in all but two secretions, tested at the lower antigen concentration only, with optical densities between $0 \cdot 17$ and $1 \cdot 59$. Optical densities in the IgE assay never exceeded $0 \cdot 06$.

IgE IN NASOPHARYNGEAL SECRETIONS

Two hundred and sixty five sequential nasopharyngeal secretions in transport medium from a total of 81 infants were tested without further dilution and at $1 / 4$ in the IgE capture assay. The single secretion from $\mathrm{Dr}$ Welliver described above was also tested. Only one secretion, designated 6757 , proved positive $(1.3 \mathrm{IU} / \mathrm{ml})$. This sample was collected immediately after diagnosis and no further secretions were available from this child. Secretions that gave optical density readings close to the 0.2 cut off were concentrated sixfold to ninefold by freeze drying and retitrated. The single positive sample, 6757, remained positive with a yield of $50 \%$. Concentrated secretion (8309) from a different child, collected 55 days after infection, proved positive with an estimated $0.36 \mathrm{IU} \mathrm{IgE/ml} \mathrm{(before}$ concentration). Secretion 8309 contained no detectable anti-RSV specific IgE either before or after concentration. Inadequate amounts of specimen 6757 were available for testing.

Secretions from a further 15 infants, diluted in PBS, were tested by antigen capture assay with enzyme amplification with a sensitivity of $0.1 \mathrm{IU} / \mathrm{ml}(240 \mathrm{pg} / \mathrm{ml})$. All 19 secretions

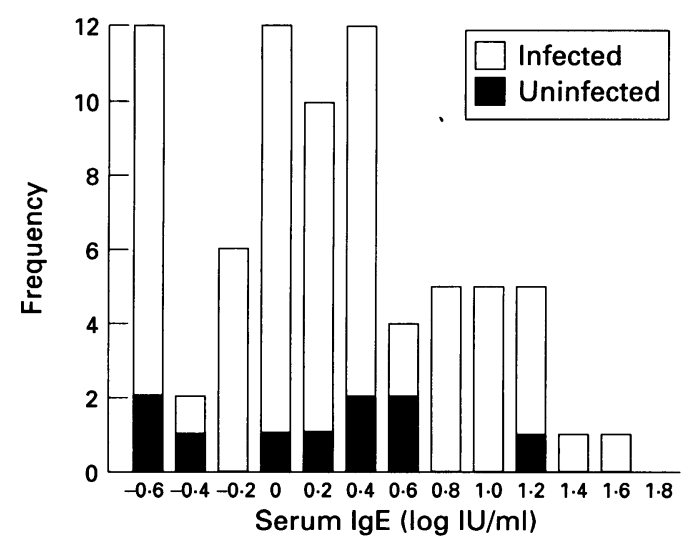

Figure 2 The frequency distribution of $I g E$ concentrations in the serum of RSV infected infants and uninfected controls. 
tested, 12 acute and seven convalescent, proved negative. Seventeen of the stored secretions from 12 infants previously tested by the unamplified assay, as described above, were retested in the amplified assay. Sixteen remained negative and only the previously positive secretion 6757 gave a strong positive signal in the amplified assay. Insufficient of secretion 8309 was available for retesting in this assay.

IgE IN SERUM

The improved IgE capture ELISA incorporating the redox enzyme amplification step was used to titrate sera from 75 infants with bronchiolitis and from 10 uninfected control children collected out of the RSV season. Sixty of the sera from infants with bronchiolitis contained detectable concentrations of IgE ranging from $0.4 \mathrm{IU} / \mathrm{ml}$ to $33 \mathrm{IU} / \mathrm{ml}$ with a geometric mean of $1.38 \mathrm{IU} / \mathrm{ml}$ (confidence limits 0.37 to $5 \cdot 12 \mathrm{IU} / \mathrm{ml}$ ). Eight of the 10 control infants contained IgE over a similar range (fig 2) with a geometric mean of 1.18 $\mathrm{IU} / \mathrm{ml}$ (confidence limits 0.31 to $4.54 \mathrm{IU} / \mathrm{ml}$ ). Second serum samples were collected after approximately six weeks from $22 \mathrm{RSV}$ infected patients. Mean serum IgE concentrations were stable in most individuals and did not differ significantly over this time period (geometric mean 1.23 , confidence limits 0.38 to 3.98 $\mathrm{IU} / \mathrm{ml})$.

\section{ASSAY OF IgE POSITIVE SERA FOR ANTI-RSV} SPECIFIC IgE

Twelve paired blood samples and four unpaired samples from a total of 16 infants with RSV infection and $\operatorname{IgE}$ in their serum were screened for IgE antibody to sucrose gradient RSV antigen and to affinity purified RSV fusion protein at a $1 / 2$ dilution. Single serum samples from an IgE negative RSV patient and an IgE positive uninfected control child were also tested. IgE bound to the virus antigen was sought using alkaline phosphatase conjugated monoclonal anti-IgE and the Ampak system. After amplification, serum negative controls revealed preferential binding of the alkaline phosphatase conjugated antiIgE to sucrose gradient purified RSV antigen coated wells when compared with wells coated with $\mathrm{HeLa}$ cell lysate at the same protein concentration. After correction for this nonspecific effect RSV specific binding achieved by sera from RSV infected infants was less than half the uncorrected values and did not significantly exceed that found in the child who was virus negative. Non-specific binding of conjugate to affinity purified fusion protein coated wells was not discernible and none of the sera tested contained detectable IgE antibodies to the fusion protein.

\section{Discussion}

In this study we have been unable to demonstrate anti-RSV specific IgE antibodies in the nasopharyngeal secretions of infants with RSV bronchiolitis using an antigen capture ELISA. A similar assay, carried out in parallel detected IgA antibodies in the secretions of all the patients tested. IgA and IgE assays differed only in the conjugated anti-immunoglobulin used and the anti-IgE peroxidase conjugate was shown to be efficacious in detecting $\operatorname{IgE}$ in an antibody capture assay. In a similar experiment carried out by Welliver et al IgA antibodies were detected in $89 \%$ of secretions while IgE antibodies were detected in $55 \% .^{13}$ Mean IgA titres were fourfold higher than mean IgE titres. Here, concentration of secretions by a factor of threefold to fourfold after freeze drying and depletion of possibly competing IgA or IgG immunoglobulins by immunoabsorption did not reveal any virus specific IgE in secretions. We are unable to explain these conflicting results.

Routine assay of $\mathrm{IgE}$ in unconcentrated nasal secretions has previously been found unreliable because of low antibody concentrations. Capture of IgE onto solid phase antigen is also complicated by competitive binding of antibody in other immunoglobulin subclasses. In the study of anti-RSV IgE in the serum of calves, Steward and Gershwin were unable to detect specific IgE antibodies on solid phase antigen until they fractionated the serum by ammonium sulphate precipitation. ${ }^{14}$ Peng et al surmounted these problems using an IgE capture ELISA increased in sensitivity by a redox amplification step and capable of detecting $\mathrm{IgE}$ in the 10 to $100 \mathrm{pg} / \mathrm{ml}$ range. ${ }^{15} \mathrm{In}$ a study of ragweed antigens in nasal secretions this assay gave lower backgrounds, better parallelism and higher sensitivity than an assay based on binding of IgE to solid phase antigen. We therefore chose to rescreen nasal secretions from infants with RSV infection for the presence of $\operatorname{IgE}$ using an amplified $\operatorname{IgE}$ capture ELISA.

When sequential secretions from 81 infants were tested by an IgE capture assay with a sensitivity of $2 \mathrm{ng} \mathrm{IgE} / \mathrm{ml}$ and secretions from a total of 27 infants were tested by the amplified version of the assay with a sensitivity of 240 $\mathrm{pg} / \mathrm{ml}$ all but two infants proved negative. We could demonstrate no RSV specific antibody in the one IgE positive secretion available for testing.

These observations are at odds with those of Russi et al who, using an RSV specific IgE capture ELISA, observed binding of antiglycoprotein antibodies to IgE captured from acute nasopharyngeal secretions of RSV infected but not uninfected infants. ${ }^{16}$ Presence of putative IgE antibodies did not correlate with wheezing. In this antigen specific IgE assay specificity relies upon the capture antibody only. Nonspecific absorption of antiviral antibodies of other subclasses or of viral antigen present in the secretions may lead to false positive results. It is noteworthy that in the study of Russi et al putative specific IgE concentrations correlated with viral antigen levels in secretions. ${ }^{16}$

That a highly specific and sensitive assay discovers no IgE in the nasal secretions of the majority of infants with RSV infection throws doubt on the association of nasal IgE and RSV 
disease. It does not preclude, however, a role for IgE antibody in the pathogenesis of bronchiolitis. Using an amplified ELISA system with a sensitivity of $240 \mathrm{pg} / \mathrm{ml}$ putative IgE was demonstrable at low concentrations in the blood of most infants, however, concentrations did not rise after infection. Polmar et $a l^{5}$ and Welliver $\mathrm{et} \mathrm{al}^{6}$ similarly found that infants aged 1 to 24 months with RSV associated bronchiolitis had low concentrations of IgE in their blood. As IgE concentrations are not consistently raised after infection it is unlikely that this is predominantly anti-RSV antibody, but some may be present. In contrast to Bui et $a l^{8}$ we were unable to demonstrate any virus specific IgE in the blood of any of the patients tested using an antigen capture ELISA with enzyme amplification. However, no attempt was made to circumvent the problem of competing antiviral IgG antibodies. This question might be investigated further using an antibody capture assay modified to detect specific antiviral IgE, although it is unclear how the specificity of any positive results can be guaranteed.

A fuller understanding of the role of IgE in the pathogenesis of bronchiolitis must await studies of the lesion in the bronchioles. Descriptions of the pathology of RSV infections are relatively rare in the literature and largely restricted to immunofluorescence staining of frozen tissue. The recent development of an anti-RSV monoclonal antibody pool that enables RSV antigen localisation in fixed and wax embedded histopathological sections (K C Oliver et al, unpublished data) affords the possibility of reinvestigation of the histopathology in larger numbers of cases and this may give a better indication of fruitful avenues for future investigation.

We wish to thank Dr Simon Court for his time and help and Professor H Simpson for serum samples and helpful discussions. The study was funded in part by a grant from the British Lung Foundation to Dr G L Toms.

1 McIntosh K, Chanock RM. Respiratory syncytial virus. In: Fields BN, Knipe DM, et al, eds. Virology. 2nd Ed. New York: Raven Press, 1990: 1045-72.

2 Pullan CR, Hey EN. Wheezing, asthma, pulmonary dysfunction 10 years after infection with respiratory syncytial vinction in years after infection with resp.

3 Gardner PS, McQuillin J, Court SDM. Speculation on pathogenesis in death from respiratory syncytial virus pathogenesis in death from

4 Sims DG, Gardner PS, Weightman D, Turner MW, Soothill JF. Atopy does not predispose to RSV bronchiolitis or postbronchiolitic wheezing. BMF 1981; 282: 2086-7.

5 Polmar SH, Robinson LD, Minnefor AB. Immunoglobulin $\mathrm{E}$ in bronchiolitis. Pediatrics $1971 ; 50: 280-4$.

6 Welliver RC, Kaul TN, Ogra PL. The appearance of cel bound IgE in respiratory tract epithelium after respiratory syncytial virus infection. $N$ Engl $f$ Med 1980; 303: 1198-202.

7 Welliver RC, Wong DT, Sun M, Middleton E, Vaughan RS, Ogra PL. The development of respiratory syncytial virus specific IgE and the release of histamine in nasopharyngeal secretions after infection. N Engl F Med 1981;

Bui

Iui RHD, Molinaro GA, Kettering JD, Heiner DC Imagawa DT, St Geme JW. Virus-specific IgE and IgG4 antibodies in serum of children infected with respiratory ; 110: 87-90.

9 Collins MA, Martinez ML, Tolpin MD. Class-specific respiratory mucosal antibody response to respiratory syncytial virus (RSV) infection. Pediatr Res 1986; 20: 817

$10 \mathrm{Ueba} O$. Respiratory syncytial virus. 1 . Concentration and purification of the infectious virus. Acta Med Okayama 1978; 4: 265-72.

11 Routledge EG, Willcocks MM, Samson ACR, et al. The purification of four respiratory syncytial virus proteins and their evaluation as protective agents against experimental infection in BALB/c mice. F Gen Virol 1988; 69: 293-303.

12 Nandapalan N, Routledge E, Toms GL. An enzyme linked immunosorbent assay (ELISA) for IgG and IgA antibodies to respiratory syncytial virus in low dilutions of 285-94.

13 Welliver RC, Sun M, Hildreth SW, Arumugham R, Ogra PL. Respiratory syncytial virus-specific antibody responses to immunoglobulin $A$ and $E$ isotypes to the $F$ and $G$ proteins and to intact virus after natural infection. f Clin Microbiol 1989; 27: 295-9.

14 Stewart RS, Gershwin LJ. Detection of IgE antibodies to bovine respiratory syncytial virus. Vet Immunol Immunopathol 1989; 20: 313-23.

15 Peng Z, Lee H-B, Proud D, Naclerio R, Adkinson JR. Ragweed IgE and IgG4 antibody in nasal secretions during immunotherapy. Clin Exp Allergy 1990; 20: 571-9.

16 Russi JC, Delfraro A, Borthagaray MD, Velazquez B, Barreno G, Hortal M. Evaluation of immunoglobulin Especific antibodies and viral antigens in nasopharyngeal secretions of children with respiratory syncytial virus infection. $\mathcal{f}$ Clin Microbiol 1993; 31: 819-23. 